\title{
Service Quality and Business Students Satisfaction in Private Ghanaian Universities. The Moderating Role of Brand Positioning
}

\author{
Nicholas Oblitei Commey ${ }^{1,2^{*}} \quad$ Kwame Adom ${ }^{2} \quad$ Aidatu Abubakar ${ }^{2}$ \\ 1. School of Business and Leadership, Heritage Christian University College, Accra-Ghana \\ P.O. Box AN 16798, Accra North \\ 2. University of Ghana Business School, University of Ghana, Accra-Ghana \\ P. O. Box LG 25, Legon
}

\begin{abstract}
Higher educational institutions face increasing competition from local and international education providers. In view of this development, most higher educational institutions focus on service quality delivery in attracting and retaining students. The objective of this study is to examine the impact of service quality on customer satisfaction and to ascertain the moderating role of brand positioning in the relationship between service quality and customer (student) satisfaction. The study adopted a quantitative approach using self-administered questionnaires to collect data from the respondents and a moderated hierarchical regression model was performed to assess the statistical interdependencies between the service quality measures and student satisfaction. The results revealed that there is a significant positive relationship between service quality and student satisfaction in Private Ghanaian Universities. The results indicate however, that brand positioning was not statistically significant in the relationship between service quality and student satisfaction as only one path was supported, which suggests that brand positioning moderates only the relationship between empathy and student satisfaction. Based on these findings, it is recommended that private universities must adopt measures to enhance on the delivery of service quality since it plays a major role in determining the satisfaction of students. One limitation is related to the scope of the study which is limited to the education industry, specifically private tertiary education industry in Ghana. Despite these limitations, the study offers practical recommendations on how private tertiary educational institutions can continue to improve on the level of student satisfaction in order to ensure their survival and profitability.
\end{abstract}

Keywords: Service Quality, Brand Positiong, Student Satisfaction, Private Universities

DOI: $10.7176 / \mathrm{JMCR} / 74-04$

Publication date: December $31^{\text {st }} 2020$

\section{Introduction}

Intense competition across products and markets has driven firms to devise strategies to gain and sustain competitive advantage in their operations. In contemporary service markets, firms, regardless of size and industry focus on quality of services offered as it plays a crucial role in gaining competitive advantage as well as attracting and retaining profitable customers.

Higher educational institutions are not isolated from the current developments in the service industry as they face an increasing competition from local and international education providers (Cassidy, Colmenares, Jones, Manolovitz, Shen, \& Vieira, 2014). Universities face increasing competition due to globalization, highly demanding students, an awareness of international rankings (Díaz-Méndez \& Gummesson, 2012) and increasing mobility of students' world-wide (Ahmad \& Hassan, 2015).

At the time of independence, Ghana had only two public universities (Acheampong, 2007). This made it difficult to gain access to the countries public universities. Statistics indicates that on the average, only about fortynine percent of qualified applicants gain admission to the public universities, and this creates a demand-supply gap of about fifty-one percent (Oduro \& Senadza, 2004). This might be due to various factors which include the limited number of enrolment offered by public universities as against the increasing numbers of senior high school graduates who are qualified to be enrolled in the countries public universities, especially with the introduction of the free Senior High Schools (SHS) in Ghana with its first graduates due in 2020. However, the last few decades has witnessed a tremendous growth in the number of universities in the country. As at 2007, Ghana has 5 public universities and over 20 private (local- and foreign-owned) university colleges (Acheampong, 2007). Currently, there are 10 public universities and 71 private higher educational institutions in Ghana (NAB, 2020). This development in the higher educational landscape in Ghana illustrates that SHS graduates who are considering gaining admissions into the countries universities have to choose from a large pool of universities.

In view of this development Tarí and Dick (2016) posited that educational institutions will continue to feel increasing pressure and demands from both their students and other stakeholders of higher education in order to close the widening gap between expectations of institutional performance and the actual performance. Again student choices and overall student behaviour will drive institutional responses in all but the most prestigious institutions (McGregor, 2017). Given the severe competition among higher educational institutions, McGregor (2017) asserted that these institutions must not be complacent about improving the student experience. This is very 
critical because there are so many options with regard to the number of universities in the world, hence the need for higher educational institutions to keep in perspective the needs and interests of such groups as students, employers, government, alumni, parents and funding agencies, among others (Rozsa, 2010).

In view of this development students are becoming extremely critical and analytical when choosing their educational institutions (Binsardi \& Ekwulugo, 2003) and as a result consider a number of factors in deciding on which universities to pursue higher (university) education. One notable factor among all that prospective students and parents consider is the quality of service offered by universities. This was verified by Donaldson \& McNicholas (2004) when they argued that when making the uncertain and high-risk decision of choosing a university, students looks for evidence of service quality (SQ), which confirms its importance in the university's function. This is because the quality of higher education as a service is fundamental to a country's development since universities prepare the professionals who will work as managers in companies and manage public and private resources and care for the health and education of new generations (Oliveria, 2009). This means that ignorance of the competitive nature of attracting students, along with the importance of measuring service quality, will ultimately be at the disadvantage to any tertiary institution (Angell, Heffernan, \& Megicks, 2008).

This development has resulted in a surge in the number of studies conducted on service quality in higher educational institutions in order to ascertain the service quality dimensions that parents and prospective students consider when deciding on which private university to pursue their education, and the impact this could have on student satisfaction (McGregor, 2017; Adikaram, Yajid, \& Khatibi, 2015; Đonlagić \& Fazlić, 2015; Giannakisa \& Bullivantb, 2015; Teeroovengadum \& Kamalanabhan, 2016; Annamdevula, 2016).

Despite the plethora of studies on service quality and student satisfaction in universities, most studies are focused on public universities (Ali, Zhou, Hussain, Nair \& Ragavan, 2016; Sultan \& Wong, 2013, Yunus et al, 2010) and in advance economies (Sultan et al., 2013; Ahmad, 2014; Khoo, Ha \& McGregor, 2017; Ali et al., 2016; Yusoff, McLeay \& Woodruffe-Burton, 2015), hence studies on service quality delivery in private universities colleges in developing economies like Ghana is under researched. Other studies also used different models like HEdPERf (Ali et al, 2016). To this end there have been several calls for studies on SQ and satisfaction to be conducted in private universities (Ali et al, 2016; Koni, Zainal, \& Ibrahim, 2013) and in developing economies like Ghana (Khoo et al., 2017; Yusoff et al.,2015; Brown \& Mazzarol, 2009; Abd, Ahmad \& Ahmed ,2013). There have also been calls to use other SQ models to investigate SQ and student satisfaction (Ali et al., 2016).

Moreover, Lee, Kim and Won (2018) are of the view that brand positioning attempts to create, change or foster specific images in the minds of consumers and it plays a vital role in overall marketing management and assessment. Lee et al, (2018) further assert that successful brand positioning influences brand preference, brand equity and loyalty. Despite the important role of brand positioning in services marketing, its role in the relationship between service quality and customer satisfaction in the higher educational industry seem to be less represented in the extant literature. This study intends to narrow the gap in literature by examining the service quality dimensions that prospective applicants and parents consider in deciding which private university to consider and its impact on customer satisfaction. It further seeks to ascertain the moderating role of brand positioning in the relationship between service quality and customer (student) satisfaction.

The study is structured as follows: The next section presents a literature review of the variables included in the study. This review provides the basis for the formulation of various research hypotheses, which are tested using a sample of 366 business students from five (5) private universities in Ghana. The paper then presents the theoretical model, with the various relations proposed between the constructs analysed, defines the measurement scales used, describes the methodological aspects of the empirical study, and presents the results obtained. The final section discusses important conclusions that can be drawn from the results obtained, analyses the implications for management, and offers a series of recommendations. The study concludes with limitations and suggestions for future research directions

\section{Literature Review}

\subsection{Students as Customers}

The literature on higher education value depicts students as service customers (Chung \& McLarney 2000; DíazMéndez \& Gummesson 2012). Yeo (2008) contends that students have been categorized as the primary beneficiaries of education and hence should be treated as customers. This perspective stems from the understanding that educational institutions are highly competitive on the market with strategies being aggressively developed to satisfy student needs in order to attract a sustainable market share (Joseph \& Joseph, 1998). Secondary beneficiaries, in this context, would include parents, the marketplace and society at large. The interplay between the two beneficiary types is, to a large extent, time and event specific. For instance, within a classroom context, students are customers to teachers; however, when students are working on an assignment for teachers, the latter becomes the customer (Johnson \& Golomskiis, 1999; Koslowski, 2006).

Rinehart (1993) offers two distinct views of students as customers; for instance, those who regard students as primary customers associate them as being involved in the input and output of the learning process. However, 
those who regard students' potential employers as primary customers argue that it is important to consider the economic reality of the situation where lesson contents should be tailored to employers' needs. Students, in both contexts, have been regarded as internal customers with the second group regarding future employers as external customers.

\subsection{Service Quality}

Perceived service quality is believed to be resulting from comparison between customers' prior expectations about the service and their perceptions after actual experience (Asubonteng, McCleary, \& Swan,1996). This is supported by Markus and Hendry (2015) when they explained that satisfaction and service quality judgments stem from a comparison between what is expected and what is received. In view of this, higher educational institutions should therefore ensure an improvement in the level of service quality and ensure higher retention rates among students (Chih, Hsu, \& Cheng, 2012) since poor service quality can lead to customer dissatisfaction or complaints (Adikaram, Yajid, \& Khatibi, 2015). Besides service outcomes, service quality perceptions also involve evaluation of the service delivery process (Parasuraman, Zeithaml, \& Berry, 1985). Hence, conceptualization of service quality ought to include both the process as well as the service outcomes (Lehtinen \& Lehtinen, 1991).

\subsection{Measures of Service Quality in Higher Educational Context}

Generally, there are many areas of disagreement in the debate over how to measure service quality, and studies have raised many questions over the principles on which the existing instruments are founded (Senthilkumar \& Arulraj, 2011). In actual fact "there seem not to be a well-accepted conceptual definition and model of service quality nor is there any generally accepted operational definition of how to measure service quality" (Seth, Deshmukh \& Vrat, 2005, p. 933).

The extant services marketing literature reveals two main approaches to measure service quality: SERVQUAL (Parasuraman, Zeithaml \& Berry, 1988) and SERVPERF (Cronin \& Taylor, 1992). Carrillat, Jaramillo and Mulki (2007) suggests that both scales are adequate and equally valid predictors of overall service quality. Among these scales, SERVQUAL has been widely used and mostly criticized. SERVQUAL is based on Oliver's expectancy-disconfirmation paradigm or EDP (Oliver, 1980). The SERVQUAL model has its theoretical foundations in the gaps model and defines service quality in terms of the difference between customer expectations and performance perceptions. The SERVQUAL scale conceptualizes service quality as containing five dimensions measured through 22 items under five headings, namely tangibles, reliability, responsiveness, assurance and empathy. The SERVQUAL instrument, "despite criticisms by a variety of authors, still seems to be the most practical model for the measurement of service quality available in the literature" and thus expectations should be considered when assessing service quality in higher education (Cuthbert, 1996b, p. 34).

The other popular measure of service quality is a performance-based approach called SERVPERF. The SERVPERF scale is the unweighted perception components of the SERVQUAL scale, which consists of 22 perception items and excludes any consideration of expectations (Sultan \& Ho, 2010). The performance-only construct, SERVPERF, demonstrates its relative superiority over the SERVQUAL scale in terms of statistical analysis. SERVPERF is a variant of the SERVQUAL scale, but this measure is based on the perception component alone. Another study also concluded that SERVPERF explained more of the variance in an overall measure of service quality than SERVQUAL (Cronin \& Taylor, 1994).

Another industry-scale called HEdPERf was developed comprising of 41 items (Firdaus, 2006a). This instrument aims at considering not only the academic components, but also aspects of the total service environment as experienced by the student. The author identified five dimensions of the service quality concept:

- Non-academic aspects - Items that are essential to enable students to fulfill their study obligations, and relate to duties carried out by non-academic staff.

- Academic aspects - responsibilities of academics.

- Reputation - importance of higher learning institutions in projecting a professional image.

- Access - Includes issues as approachability, ease of contact, availability and convenience.

- Program issues - Importance of offering wide ranging and reputable academic programs/specializations with flexible structures and health services.

Mahapatra and Khan (2007) also developed a systematic integrated approach for modelling customer evaluation of service quality applied to technical education through a survey instrument known as EduQUAL, specifically proposed for the education sector, which is used to measure the satisfaction level of different stakeholders.

For the purpose of this study the SERVQUAL model was adopted to examine service quality in private universities since it has been the foundation on which all other studies on service quality has been built (Rood \& Dziadkowiec, 2013). 


\subsection{SERVQUAL Dimensions}

According to the SERVQUAL scale, quality is perception-minus-expectation. It has five dimensions and 22 items. These dimensions are reliability, assurance, tangibles, empathy, and responsiveness (Parasuraman et al., 1988).

The reliability construct of the SERVQUAL model represents the service provider's ability to perform the promised service dependably and accurately (Zeithaml, Berry \& Parasuraman, 1996). This is achieved through keeping promises to do something, providing right service, consistency of performance and dependability, performance of service right at the first time, the company keeping its promises in accuracy in billing and keeping records correctly, available merchandise and error-free sales transactions (Zeithaml et al., 1996). Reliability further consists of accurate order fulfilment; accurate record; accurate quote; accurate billing; accurate calculation of commissions, keeping services promise (Zineldin, 2006). In the context of higher education, reliability relates to the ability of the university to perform the promised services dependably and accurately.

Tangibility relates to the physical aspects or evidence of a service and is considered as very crucial in the provision of services because the higher customers appreciate the physical aspects, the higher the overall evaluation of service quality (Bellini, Lunard \& Henrique, 2005). Physical aspects of a service include appearance of equipment and fixtures, physical facilities, materials associated with the service, appearance of personnel and communication materials, convenience of physical facilities and layouts (Zeithaml et al., 1996). In addition to the appearance of facilities, tangibility also takes into account the convenience offered the customer by the layout of physical facilities (Ananth, Ramesh \& Prabaharan, 2011). Bitner (1992) proposed that the physical setting of the place of service, including not only visual aspects such as colour and texture, but also noise, odour and temperature is of particular importance and capable of altering customer expectations and strongly influencing consumer responses and satisfaction. According to Kim and Jin (2002) the professional appearance of staff is also an important means of tangibilizing the intangible service products. Furthermore, the tangibles of a service or service provider can be represented by the physical appearance of employees and other physical infrastructures. This has also seen the introduction of a dress code or uniform for bank employees in certain countries (Kim et al., 2002). In the context of higher education tangibles relates to the appearance of the university's physical facilities, equipment, personnel, and communication materials.

The assurance construct consists of competence (possession of the required skills and knowledge to perform the service), courtesy (consideration for the customer's property, clean and neat appearance of public contact personnel), credibility and security of the employees and their ability to inspire trust and confidence (Zeithaml et al., 1996). According to Zainal, Shaharudin, and Jusoff (2010), assurance includes employees having knowledge to answer questions, inspiring confidence, providing prompt service, willing to respond to customers' requests, giving customers individual attention, showing consistent courtesy with customers and even treat customers properly on the phone. Parasuraman, Berry and Zeithaml (1991) included actions by employees such as always being courteous, behaviours that instil confidence and knowledge as prime elements of assurance. In the context of higher education, assurance relates to the knowledge and courtesy of lecturers and their ability to convey trust and confidence.

Responsiveness is the determinant that defines the willingness to help customers and to provide prompt services. It is the desire and willingness to assist customers and deliver prompt service (Parasuraman, Zeithaml \& Berry, 1985). It involves features such as the opening hours of the service provider, the politeness of the employees and the time the customer has to wait in order to get the service. In other words, it describes how quickly and affective the response to the customer is (Zeithaml et al., 1996). It also involves understanding needs and wants of customers, convenient operating hours, individual attention given by the staff, attention to problems and safety of customers' transaction (Kumar, Mani, Mahalingam, \& Vanjikovan, 2010). In relation to this dimension Yeo (2008) opined that institutions should be responsive to the shifting needs of their students in providing courses and training programmes that are relevant in the subject matter and teaching approaches. In the context of higher education, responsiveness involves the willingness of the university to help students and provide prompt service.

The last dimension of the SERVQUAL model is empathy. Empathy is the caring and personalized attention the organization provides its customers. It is reflected in the service provider's provision of access, communication and understanding the customer (Parasuraman et al., 1988). Individual attention, convenient operating hours, understanding of the customers when a problem occurs and the knowledge the employees have of the customers' needs were the primary elements included in evaluation of empathy. This dimension captures aspects of service quality that are directly influenced by the service provider's policy such as good customer service, convenience of parking and operating hours (Butcher, Sparks, \& O'Callaghan, 2001; Ndubisi, 2007; Ehigie, 2006). The degree to which the customer feels the firms' empathy will cause the customer to either accept or reject the service encounter. The higher the level of empathy, the higher the overall evaluation of retail service quality. Yeo (2008) noted that it is sometimes a challenge for institutions to exceed customer expectations and demands since sometimes a shortage of teaching staff and the need for optimal enrolments have seen an increase in class sizes, stretching the teacherstudent ratio and this development has implication on the level of individual attention and empathy given to each student inside and outside class. Further, when teachers are expected to assume multiple roles including curriculum 
writing, stand-up teaching, mentoring, and project supervising and administrative responsibilities, the level of service quality may become less standardized and desirable over time (Yeo, 2008). In the context of higher education empathy involves the caring, individualized attention the university provides its students.

\subsection{Customer (Student) Satisfaction}

Customer satisfaction is very essential to every organization since satisfied customers are always more credible to be loyal to a firm (Lee \& Lin, 2005) and also tend to be less price sensitive, buy more of the firm's products, are hardly influenced by competitors and are known to stay longer in a relationship with the provider (Zineldin, 2000). Kotler and Keller (2006) explained satisfaction as a person's feeling of pleasure or disappointment which results from comparing the performance of the product to his or her expectation. This is in line with the explanation by Oliver (1999) that customer satisfaction is consumers' post purchase evaluation and affective response to the overall product or service experience. Customer satisfaction is said to enhance customer retention (Ericksson \& Lofmarck, 2000). It is also noted that service quality and customer satisfaction are directly related as high quality enhances the satisfaction at the same time (Hamad \& Naintara, 2014).

Within the context of higher education, satisfaction is perceived as "a short-term attitude resulting from an evaluation of a student's educational experience" (Elliott \& Healy, 2001, p.2). For higher educational institutions in particular, satisfaction may influence a student's desire to remain with or leave the college, and their inclination to provide word-of-mouth recommendations (McGregor, 2017). A study by Purgailis and Zaksa's (2012) reveal that student-perceived quality correlates with factors such as academic staff, study content, readiness for labour market and acquired skills which consequently have an influence on student loyalty to higher educational institutions. Again a study by Gruber et al. (2010) indicates that student satisfaction reflects the perception of service quality differences exhibited by the educational institutions.

\subsection{Brand Positioning}

Positioning is explained as the way a company wants customers to perceive, think and feel about its brand versus competitive entries (Janiszewska \& Insch, 2012). This implies that brand positioning is of a high level of subjectivity since it refers to the customer's individual perceptions (Janiszewska \& Insch, 2012). Davis (2000) perceives the notion of brand positioning in a similar way. In his opinion positioning is the place in consumers' minds that a brand wants to own. It has to be externally driven and relevant, it has to be differentiated from the competition and, most importantly, it has to be valued. Positioning is a systematic process or set of strategic steps adopted by marketers to conspicuously attract attention, catch and seize the eyes, and implant the brand in the minds of buyers and users (Edema, 2012). Edema, 2012 termed this as a concoction or a mix of flavorings to woo customers.

Keller (1998) emphasizes that arriving at the proper position requires establishing the correct point of difference (unique to the brand) and point of parity association (connected with the category, not necessarily unique to the brand). Temporal (2002) notes that positioning is vital to brand management because it takes the basic tangible aspects of the product and actually builds the intangibles in the form of an image in people's minds. Marketing experts agree on the essence of positioning, namely assuming a desired position in the audience's awareness by owning a specific set of associations in the context of competition (Ellwood 2009). This implies that any strategic decisions related to building up and developing a brand refer to the assumptions behind the positioning.

\section{Theoretical Framework and Hypothesis}

The theoretical framework and hypothesis was developed based on the objectives of the study and the review of literature related to the study.

\subsection{Service Quality Dimensions and Satisfaction}

The relationship between service quality dimensions and customer satisfaction has received considerable attention in the marketing literature (Brady, Cronin, \& Brand, 2002; Cronin \& Taylor, 1992; Meuter et al., 2000; Olorunniwo, Hsu \& Udo, 2006; Zeithaml et al., 1996). A study by Khoo et al., (2017) revealed significant positive relationships between perceived service quality dimensions and satisfaction in the tertiary education industry. Zeithaml and Bitner (2003) also confirmed that customer satisfaction is influenced by customer's perceptions of quality. It was also revealed that service quality is an antecedent of the broader concept of customer satisfaction (Gotlieb, Dhruv, \& Brown, 1994; Buttle, 1996; Zeithaml \& Bitner, 1996). Previous studies have also found direct and indirect links between the service quality dimensions and satisfaction (Ledden, Kalafatis, \& Mathioudakis, 2011; Wu, 2013; Zaibaf, Taherikia, \& Fakharian, 2013). In the context of higher education, one study revealed that service quality affects satisfaction through perceived value (Brown \& Mazzarol, 2009). Ali et al., (2016) also assert that service quality in the field of higher education has a significant positive influence on student satisfaction. Another study examines service quality-satisfaction relationship using the European customer satisfaction index (ECSI) model, 
and finds that service quality directly affects satisfaction (Alves \& Raposo, 2007). Based on the review of literature, the authors developed the following hypothesis:

H1: There is a positive significant relationship between reliability and students' satisfaction

H2: There is a positive significant relationship between assurance and students' satisfaction

H3: There is a positive significant relationship between tangibility and students' satisfaction

H4: There is a positive significant relationship between empathy and students' satisfaction

H5: There is a positive significant relationship between responsiveness and students' satisfaction

\subsection{Moderating Role of Brand Positioning Between Service Quality Dimensions and Satisfaction}

Past studies in service literature have found several variables that influence the service quality-satisfaction relationship, including the existence of some moderator variables (Ledden, Kalafatis, \& Mathioudakis, 2011; Wu, 2013; Zaibaf, Taherikia, \& Fakharian, 2013). Dimensions such as image and reputation have been recognized as some of the key determinants affecting prospective student decisions when making a choice of university to attend (Berger \& Wallingford, 1996; Sevier, 1994). Brands are also recognized as an effective tool to enhance student loyalty and as a result education providers need to manage not only academic factors, but also the brand positioning of their institutions (Angulo-Ruiz \& Pergelova, 2013). In the context of higher education, overall university image influences student satisfaction (Palacio, Meneses, \& Perez, 2002) and universities with positive images will be better positioned to foster graduate satisfaction (Schlesinger, Cervera, \& Pérez-Cabañero, 2017). This is important because brands have been regarded as an indicator of quality in the education sector (Judson, Aurand, Gorchels, \& Gordo, 2009; Lee, Miloch, Kraft, \&Tatum, 2008). A strong university brand can lead to perception of excellent quality (Palacio et al., 2002), enabling universities to regard itself as a top, leading, or world-class university (Belanger, Mount, \& Wilson, 2002).

Palacio et al. (2002) posited that affective, cognitive, and overall image of a university is positively associated with student satisfaction. Brown \& Mazzarol (2009) found that satisfaction is affected by the perceived overall image of the university and according to Alves and Raposo (2010), perceived quality develops a favorable image in the minds of students which subsequently leads them to satisfaction. Based on this, the authors hypothesise that:

H6a: Brand position moderates the relationship between reliability and students' satisfaction

H6b: Brand position moderates the relationship between assurance and students' satisfaction

H6c: Brand position moderates the relationship between tangibility and students' satisfaction

H6d: Brand position moderates the relationship between empathy and students' satisfaction

H6e: Brand position moderates the relationship between responsiveness and students' satisfaction

Figure1: Conceptual Framework

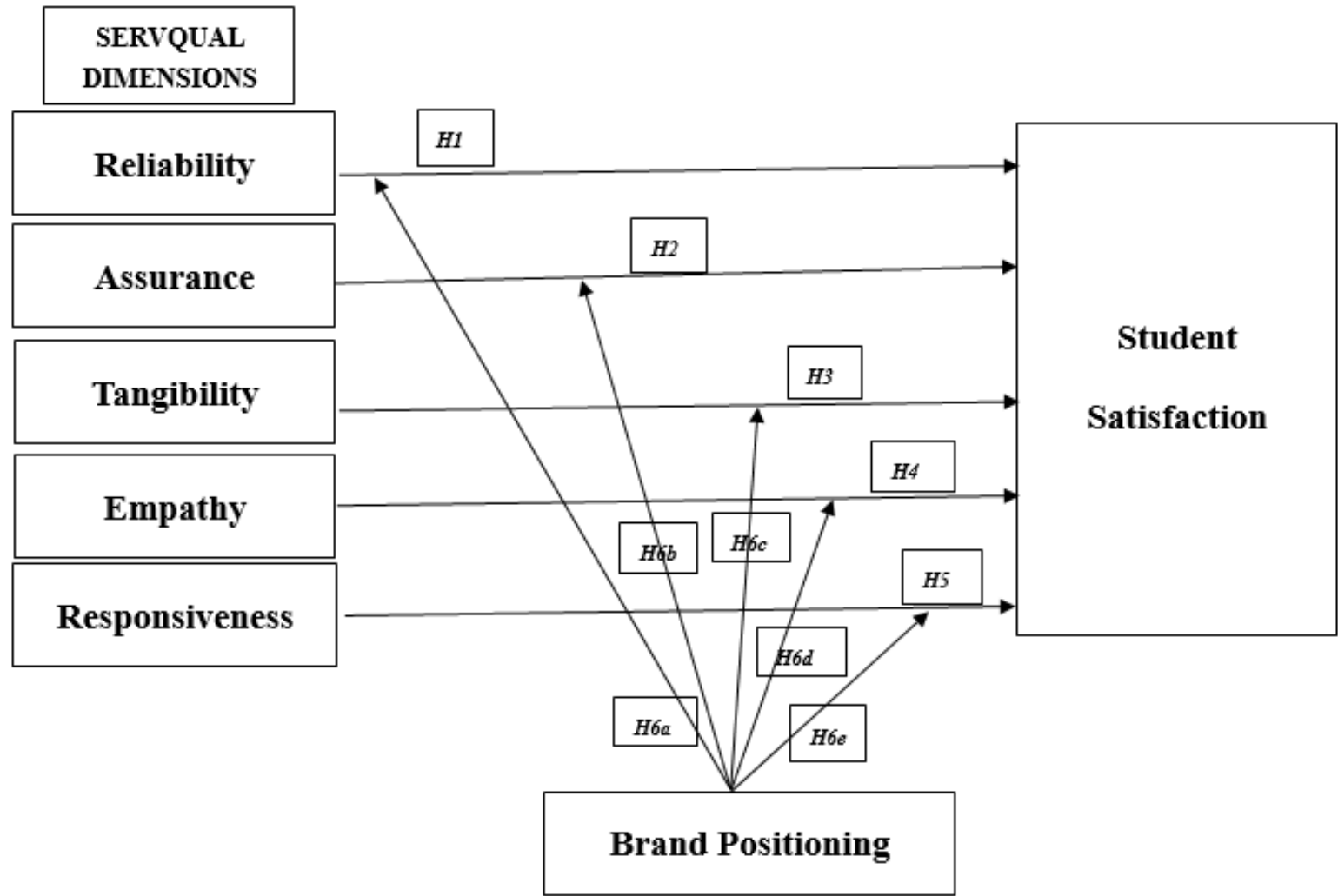




\section{Methodology}

The objective of this study is to investigate the impact of service quality on student satisfaction in Private Ghanaian Universities by considering the moderating role of brand positioning. The study adopted a quantitative approach using self-administered questionnaires to collect data from the respondents. One set of questionnaire was developed for the selected private universities involved in the study. The questionnaire was divided into two parts, thus Section A and Section B. Section A is made up of questions concerning the background of the respondents. Section B is subdivided into seven parts. These parts contain questions relating to the service quality measures, brand positioning, and customer satisfaction. The questionnaires were distributed among business students of the five (5) private universities in the Greater Accra Region of Ghana selected for the study. These private universities were selected because they all run business programmes and have operated in Ghana for a number of years and as a result could make it possible to get the required data to conduct this study.

In all, 366 out of the 500 questionnaires distributed representing 73.2 per cent was analysed. A large sample size was adopted in order to reduce the probability of errors (Burns, 2000). The data was analysed using IBM SPSS version 22 as well as IBM AMOS version 23 . The scale items were subjected to reliability checks to ascertain their internal consistency (Neuman, 2007). Cronbach's Alpha values were also used as a benchmark to check the reliability of the scale items. The constructs had Cronbach's alpha values ranging from 0.70 to 0.86 . After this, validity was assessed with a seven factor CFA measurement model which comprised all the theoretical measures (Arbuckle, 2006). A moderated hierarchical regression model was then performed to assess the statistical interdependencies between the service quality measures and student satisfaction.

\section{Data Analysis, Interpretation and Results 5.1 Profile of Respondents}

Statistical data analysis was carried out using IBM SPSS version 22 as well as IBM AMOS version 23. A total of 366 valid responses out of 500 questionnaires distributed were found usable for further analysis. The valid responses indicate that, $55.2 \%$ of the respondents were male while $44.8 \%$ were female. Majority of the respondents $(57.9 \%)$ were aged between 21 to 25 with just $0.5 \%$ of them aged between 46 and 50 . Most of the respondents $(51.9 \%)$ were in their fourth year of study while $2.2 \%$ were in their first year. Table 1 provides the details on profile of respondents.

Table 1: Profile of Respondents

\begin{tabular}{lcc}
\hline & Frequency & Percentage \\
\hline Gender & 164 & 44.8 \\
Male & 202 & 55.2 \\
Female & & \\
Age & 35 & 9.6 \\
Less than 20 & 212 & 57.9 \\
$21-25$ & 60 & 16.4 \\
$26-30$ & 32 & 8.7 \\
$31-35$ & 14 & 3.8 \\
$36-40$ & 11 & 3 \\
$41-45$ & 2 & 0.5 \\
$46-50$ & & \\
Level & 8 & 2.2 \\
Level 100 & 60 & 16.4 \\
Level 200 & 85 & 23.2 \\
Level 300 & 190 & 51.9 \\
Level 400 & 23 & 6.3 \\
Level 500 and above & & \\
\hline
\end{tabular}

\subsection{Descriptive Statistics}

Mean statistics helps to examine the central tendency of the various constructs adopted for the study. Table 2 indicates that the highest mean is 3.8251. This is in relation to whether employees of private universities are well dressed and appear neat. This shows that most of the respondents, in this case the students in the five (5) private universities selected for the study agreed that employees of the various private universities dress well and are neat. This implies that students in private universities consider how employees in the various institutions dress and it contributes significantly to student satisfaction. In line with this findings, it is recommended that private universities must ensure that all staff, whether academic or non-academic are always well dressed in order to enhance student satisfaction. The least mean score is 2.7131 . This is in relation to whether students consider private universities to be sympathetic and reassuring when students encounter challenges in the course of their stay. The score is closer to 3 on the Likert scale of 1 to 5 which represents neutral. This indicates that students are not sure 
as to whether their various universities are sympathetic and reassuring when they encounter challenges in the course of their stay. This could imply that private universities are not doing enough to assist students when they encounter challenges, hence may have a negative effect on student satisfaction. Based on this finding, it is recommended that private universities provide regular training on customer service for all staff in order to make it a regular part of all employees. This can impact positively on student satisfaction since that can provide students a sense of reassurance on the part of all staff. This is illustrated in table 2.

Table 2: Descriptive Statistics of Variables

\begin{tabular}{|c|c|c|c|c|c|}
\hline & $\mathbf{N}$ & Min & Max & Mean & $\begin{array}{c}\text { Std. } \\
\text { Deviation }\end{array}$ \\
\hline $\begin{array}{l}\text { The institution's physical facilities are visually } \\
\text { appealing }\end{array}$ & 366 & 1.00 & 5.00 & 3.1940 & 1.12655 \\
\hline $\begin{array}{l}\text { The institution's employees are well dressed and } \\
\text { appear neat }\end{array}$ & 366 & 1.00 & 5.00 & 3.8251 & 1.03475 \\
\hline The institution's equipment are up-to-date & 366 & 1.00 & 5.00 & 2.7978 & 1.19249 \\
\hline $\begin{array}{l}\text { The appearance of the physical facilities of the } \\
\text { institution is in keeping with the type of service } \\
\text { provided. }\end{array}$ & 366 & 1.00 & 5.00 & 3.1202 & 1.04778 \\
\hline $\begin{array}{l}\text { The institution has an ideal location with convenient } \\
\text { campus layout and physical facilities }\end{array}$ & 366 & 1.00 & 5.00 & 3.6284 & 1.06946 \\
\hline $\begin{array}{l}\text { When you have problems the institution is } \\
\text { sympathetic and reassuring. }\end{array}$ & 366 & 1.00 & 5.00 & 2.7131 & 1.23740 \\
\hline $\begin{array}{l}\text { The institution provides its services at the time it } \\
\text { promises to do so }\end{array}$ & 366 & 1.00 & 5.00 & 3.0656 & 1.22801 \\
\hline The institution's employees are courteous & 366 & 1.00 & 5.00 & 3.5464 & 1.01591 \\
\hline The institution's employees give us special attention & 366 & 1.00 & 5.00 & 3.2213 & 1.07407 \\
\hline The institution handles our requests promptly & 366 & 1.00 & 5.00 & 2.7295 & 1.13984 \\
\hline The institution keeps accurate and retrievable records & 366 & 1.00 & 5.00 & 3.4973 & 1.08980 \\
\hline $\begin{array}{l}\text { The institution tells its students exactly when services } \\
\text { will be performed }\end{array}$ & 366 & 1.00 & 5.00 & 3.4836 & 1.06424 \\
\hline $\begin{array}{l}\text { The institution's employees are always willing to } \\
\text { help students }\end{array}$ & 366 & 1.00 & 5.00 & 3.4372 & 1.08040 \\
\hline $\begin{array}{l}\text { The institution's employees always provides prompt } \\
\text { service }\end{array}$ & 366 & 1.00 & 5.00 & 3.1393 & 1.02288 \\
\hline $\begin{array}{l}\text { The institution's employees are never too busy to } \\
\text { respond to student's request for assistance }\end{array}$ & 366 & 1.00 & 5.00 & 3.1585 & 1.13332 \\
\hline I trust the competence of the institution's employees & 366 & 1.00 & 5.00 & 3.5000 & .97292 \\
\hline $\begin{array}{l}\text { I feel safe/secure in my interactions with the } \\
\text { institution's employees }\end{array}$ & 366 & 1.00 & 5.00 & 3.4809 & 1.01140 \\
\hline $\begin{array}{l}\text { I have confidence in the credibility of the institution's } \\
\text { employees }\end{array}$ & 366 & 1.00 & 5.00 & 3.5000 & .92677 \\
\hline $\begin{array}{l}\text { The institution's employees inspire trust and } \\
\text { confidence among students }\end{array}$ & 366 & 1.00 & 5.00 & 3.4754 & 1.00312 \\
\hline $\begin{array}{l}\text { The institution's employees show consistent courtesy } \\
\text { in their interactions with students }\end{array}$ & 366 & 1.00 & 5.00 & 3.3907 & .99743 \\
\hline $\begin{array}{l}\text { The institution's employees knows what I actually } \\
\text { need }\end{array}$ & 366 & 1.00 & 5.00 & 2.8634 & 1.05359 \\
\hline $\begin{array}{l}\text { The institution's employees have my best interest at } \\
\text { heart }\end{array}$ & 366 & 1.00 & 5.00 & 3.0492 & 1.06387 \\
\hline $\begin{array}{l}\text { The institution operates according to the business } \\
\text { hours that are convenient to me }\end{array}$ & 366 & 1.00 & 5.00 & 3.4426 & 1.04985 \\
\hline $\begin{array}{l}\text { The institution's employees provides caring and } \\
\text { individual attention }\end{array}$ & 366 & 1.00 & 5.00 & 3.1257 & 1.06529 \\
\hline $\begin{array}{l}\text { The institution's employees communicates and } \\
\text { understands students concerns }\end{array}$ & 366 & 1.00 & 5.00 & 3.1913 & 1.06836 \\
\hline I am completely happy with the institution & 366 & 1.00 & 5.00 & 3.0683 & 1.19048 \\
\hline I am very pleased with my institution's services. & 366 & 1.00 & 5.00 & 3.0273 & 1.10010 \\
\hline $\begin{array}{l}\text { My experiences with my institution have always been } \\
\text { good. }\end{array}$ & 366 & 1.00 & 5.00 & 3.1284 & 1.10164 \\
\hline Overall, I am very satisfied with my institution & 366 & 1.00 & 5.00 & 3.1339 & 1.16624 \\
\hline
\end{tabular}




\begin{tabular}{lccccc}
\hline & & & & & $\begin{array}{c}\text { Std. } \\
\text { Deviation }\end{array}$ \\
\hline $\begin{array}{l}\text { If I had to do it all over again, I would still choose } \\
\text { this institution }\end{array}$ & 366 & 1.00 & 5.00 & 2.9863 & 1.34972 \\
I consider institutions I am aware of & 366 & 1.00 & 5.00 & 3.4945 & .95299 \\
I consider institutions I I perceive to be different & 366 & 1.00 & 5.00 & 3.5109 & .95294 \\
I consider institutions I perceive to be credible & 366 & 1.00 & 5.00 & 3.6721 & .98015 \\
I consider the reputation of institutions in my & 366 & 1.00 & 5.00 & 3.7158 & .96294 \\
selection & 366 & 1.00 & 5.00 & 3.6831 & 1.09449 \\
I consider institutions that support society & & & & & Max
\end{tabular}

\subsection{Reliability and Validity of Measurement Model}

The scale items were subjected to reliability checks to test their internal consistency (Neuman, 2007). The Cronbach's Alpha values were used as a benchmark to check the reliability of the scale items. According to Hair, Babin and Anderson (2010) Cronbach's Alpha value of 0.6 was the lower limit of acceptability. The constructs had Cronbach's alpha values ranging from 0.70 to 0.86 . The results of the reliability test are shown in table 3 . Following the guidelines of Anderson and Gerbing's (1988) construct, validity was assessed with a seven factor CFA measurement model which comprised all the theoretical measures (Arbuckle, 2006). For our sample, the standardized factor loadings for each individual item on its respective constructs were statistically significant ( $p$ $<0.01)$ and adequately greater than an arbitrary 0.50 (Hair et al., 2010). The model fit the data well $(\chi 2 / \mathrm{df}=1.91$, $\mathrm{P}<0.01, \mathrm{IFI}=0.93, \mathrm{CFI}=0.93, \mathrm{TLI}=0.92, \mathrm{RMSEA}=0.05)$. These values demonstrate the dimensionality of the constructs, an indication that the constructs demonstrate sufficient convergent validity. Correlation for each construct was higher than the correlation coefficients of the corresponding inter-constructs, confirming the adequacy of discriminant validity (Fornell \& Larcker, 1981). The results of the correlation are presented in table 3.

Table 3: Model Reliability and Validity

\begin{tabular}{lclllllll}
\hline Correlations & Cronbach' Alpha & $\mathbf{1}$ & $\mathbf{2}$ & $\mathbf{3}$ & $\mathbf{4}$ & $\mathbf{5}$ & $\mathbf{6}$ & $\mathbf{7}$ \\
\hline Tangibility & 0.71 & 1 & & & & & & \\
Responsiveness & 0.83 & $.551^{*}$ & 1 & & & & & \\
Reliability & 0.78 & $.531^{*}$ & $.701^{*}$ & 1 & & & & \\
Assurance & 0.84 & $.527^{*}$ & .650 & $.669^{*}$ & 1 & & & \\
Empathy & 0.78 & $.483^{*}$ & $.597^{*}$ & $.601^{*}$ & $.679^{*}$ & 1 & & \\
satisfaction & 0.84 & $.429^{*}$ & $.593^{*}$ & $.561^{*}$ & $.530^{*}$ & $.514^{*}$ & 1 & \\
Brand Positioning & 0.86 & $.405^{*}$ & $.447^{*}$ & $.380^{*}$ & $.482^{*}$ & $.438^{*}$ & $.386^{*}$ & 1 \\
\hline
\end{tabular}

** Correlation is significant at the 0.01 level (2-tailed).

\subsection{Moderated Hierarchical Regression}

A moderated hierarchical regression model was performed to assess the statistical interdependencies between service quality dimensions and satisfaction within the context of Private Ghanaian Universities. The rationale for choosing hierarchical regression is hinged on the fact that it utilizes an interactive method with a complementarity procedure after deriving initial residuals independently on each of the moderator and predictor variables (Aiken \& West, 1991). Hence, beyond the contribution made by the independent variable, a moderated hierarchical regression model aids in identifying the exact contribution made by the moderator in the relationship between the independent and the dependent variable (Odoom \& Mensah, 2018). In order to do this, the averages of the constructs were taken to develop composite scores as a means of minimizing model complexity (Ping, 1995). Afterwards, constructs that needed to be interacted were mean-centered to cater for the possible risk of multicollinearity and to clarify the interaction effects (Aiken \& West, 1991). To reduce the possibility of endogeneity as a result of the use of continuous scales on the study's constructs, the hypotheses were tested through a multistage hierarchical regression. The results are presented in table 4.

First, we assessed the effects of the control variables (age and gender) on satisfaction in model 1 . The results depicted the control variables explained 0.06 percent of the variance in satisfaction, as expected, the effect was not statistically significant. Second, the effects of all the predictor variables were added to model 1 in Model 2 to gain outcomes devoid of the effects of the moderating variable in order to help evaluate the explanatory power in all models. In model 2, we tested our first five hypotheses. Model 2 showed a significant rise in $\mathrm{R}^{2}$ by $0.414(\mathrm{P}<$ 0.000), the model explained 42 percent of the variance in satisfaction. The results at this stage revealed that, responsiveness $(\mathrm{P}=0.000)$, reliability $(\mathrm{P}=0.005)$ and empathy $(\mathrm{P}=0.017)$ had significant positive effect on 
satisfaction. However, tangibility and assurance had insignificant effects on satisfaction. In Model 3, we added the moderating variable, which is brand positioning devoid of interaction terms to ascertain its explanatory power. Results from this model indicated a slight change in $\mathrm{R}^{2}$ by 0.5 percent $(\mathrm{P}=0.85)$, however, the effect was not statistically significant. Finally, in model 4 , we added the interaction terms. Model 4 showed an increase in $\mathrm{R}^{2}$ by $2.7 \%(\mathrm{P}=0.002)$ and the model explained 45.2 percent of the variance in satisfaction. The results from this model demonstrated that the interaction term of brand positioning and the dimensions of service quality do not have a significant effect on satisfaction with the exception of empathy $(\beta=1.49, \mathrm{t}=4.00, \mathrm{P}=0.000)$.

Table 4: Moderated Hierarchical Regression

\begin{tabular}{lllll}
\hline Variables & Model 1 & Model 2 & Model 3 & Model 4 \\
\hline Control Variables & & & & \\
Age & $-0.004(-0.077)$ & $-0.004(-0.104)$ & $0.007(0.178)$ & $0.008(0.193)$ \\
Gender & $-0.075(-1.427)$ & $-0.002(-0.039)$ & $-0.006(-0.146)$ & $0.003(0.071)$ \\
Independent Variables & & & & \\
Tangibility & & $-0.055(1.080)$ & $0.042(0.811)$ & $-0.282(-1.162)$ \\
Responsiveness & & $0.291(4.656)$ & $0.276(4.372)$ & $-0.205(-0.750)$ \\
Reliability & & $0.179(2.822)$ & $0.186(2.943)$ & $0.227(0.824)$ \\
Assurance & & $0.097(1.518)$ & $0.076(1.185)$ & $0.103(1.612)$ \\
Empathy & & $0.140(2.404)$ & $0.128(2.185)$ & $1.049(4.434)$ \\
Brand Positioning & & & $0.083(1.726)$ & $0.188(1.074)$ \\
Brand positioning x Tangibility & & & & $0.548(1.378)$ \\
Brand positioning x Responsiveness & & & & $0.722(1.799)$ \\
Brand positioning x Reliability & & & & $-0.016(-0.037)$ \\
Brand positioning x Empathy & 0.006 & 0.420 & 0.425 & $1.490(4.005)$ \\
$\mathrm{R}^{2}$ & 0.000 & 0.409 & 0.412 & 0.452 \\
Adjusted R & & & 0.434 \\
$\mathrm{R}^{2}$ change & 0.006 & 0.414 & 0.005 & 0.027 \\
F Change & 0.362 & 0.000 & 0.085 & 0.002 \\
\hline
\end{tabular}

Notes: Dependent variable=Satisfaction, standardized beta coefficients are outside parentheses, t-values are reported in parentheses.

\section{Discussion of Results}

The main objective of this study is to investigate the impact of service quality dimensions on student satisfaction in Private Ghanaian Universities and to examine the moderating role of brand positioning in the relationship between service quality dimensions and student satisfaction. The study revealed that age and gender does not account for a significant variation in the level of student satisfaction in private universities in Ghana. This is consistent with the study by Clemes, Gan \& Kao (2008) which also revealed that age groups exhibit no perceptual differences between the dimensions. However, it contradicts previous findings by Clemes et al. (2001) which indicated otherwise.

Specifically, the results for $H 1$ revealed that there is a positive significant relationship between reliability and student satisfaction. This indicates that $\mathrm{Hl}$ is supported. This is consistent with the findings of studies by Khoo et al. (2016), Adikaram at al. (2015) and Ham and Hayduk (2003) which also revealed that there is a positive relationship between reliability and student satisfaction. This implies that when private universities perform the promised service dependably and accurately and they ensure consistency of performance and performance of service right at the first time, students will be delighted with their service delivery, hence will be satisfied. This finding is however, contrary to the findings of the study by Hasan and Ilias (2008) which revealed that reliability does not contribute significantly to the level of student satisfaction.

Additionally, the outcome for $\mathrm{H} 2$ revealed that the relationship between assurance and student satisfaction is not significant, hence $H_{2}$ is rejected. This is contrary to previous studies by Khoo et al. (2016), Adikaram et al. (2015), Hasan and Ilias (2008) and Ham and Hayduk (2003) which indicates that assurance contributes significantly to student's satisfaction. This suggest that the ability of both academic and non-academic staff to inspire trust and confidence does not contribute significantly in determining the level of student satisfaction in Private Ghanaian Universities. What might account for this is the fact that although most students will prefer to obtain university degrees by enrolling in public universities, they do not gain admission into these universities in view of the huge number of applications into the countries public universities. Hence, the alternative is to apply for admission into any of the private universities in order for them to obtain the much needed certificates which will help them in securing high paying jobs and also to gain promotions at their various institutions of employment.

The results for $H 3$ indicates that the relationship between tangibility and student satisfaction is not significant, therefore $H 3$ is rejected. This is consistant with the study by Hasan and Ilias (2008) which indicates that tangibility does not contribute significantly to students satisfaction. This indicates that tangibility is not a very important 
factor in determining student satisfaction in private universities (Cuthbert's (1996a, b). This implies that the physical aspects of a service which include appearance of equipment and fixtures, physical facilities, appearance of personnel and communication materials, convenience of physical facilities and layouts does not contribute significantly in determining the level of student satisfaction. This finding is contrary with the findings of the study by Khoo et al. (2016), Adikaram et al. (2015) and Ham and Hayduk (2003) which revealed that there is a positive relationship between tangibility and student satisfaction.

The results for $\mathrm{H} 4$ also revealed a significant relationship between empathy and student satisfaction, indicating that $\mathrm{H} 4$ is also supported. This is consistent with the findings of the study by Khoo et al. (2016), Adikaram et al. (2015), Hasan and Ilias (2008) and Ham and Hayduk (2003) which indicates that assurance contributes significantly to student's satisfaction. This means that the caring and personalized attention the university provides its students determines the extent of student satisfaction.

Finally, the results for $\mathrm{H5}$ also indicates a positive relationship between responsiveness and student satisfaction, indicating that $H 5$ is supported. This is consistent with the study by Khoo et al. (2016), Adikaram et al. (2015) and Ham and Hayduk (2003) which revealed that there is a positive relationship between responsiveness and student satisfaction. This also suggests that the desire and willingness to assist students and deliver prompt service and ensuring the politeness of the employees when offering services to students is considered very crucial in ensuring the satisfaction of students.

For H6 (a-e), only one path is supported, thus all the paths suggesting the various hypothesis were rejected with the exception of H6d which suggests that brand positioning moderates only the relationship between empathy and student satisfaction. This implies that the brand positioning of a private university plays a role in determining the extent to which empathy can determine the extent of student satisfaction, but does not in general significantly moderate the relationship between service quality and student satisfaction. This finding is in line with the findings of the study by Clemes, Gan and Kao (2008) which indicates that brand image has only a minor impact on satisfaction. This is contrary to Mai's (2005) finding that the overall impression of a school had a strong influence on satisfaction. It is also contrary to a study by Andressen and Lindastad (1998) which suggests that image has a larger impact on satisfaction when people lack knowledge about an organization through their own experiences. The findings of this study also contests the findings of previous studies which indicate that brand image within universities and other educational institutions is key in service delivery (Brown \& Mazzarol, 2009) and the fact that the findings of the study by Palacio, Menses and Perez's (2002) indicates that university image has a significant relationship with student satisfaction.

On the whole, the study revealed that there is a positive relationship between service quality and student satisfaction. This findings on the whole is consistent with the outcome of the study by Haeruddin et al., (2020) which revealed that there is a positive and significant relationship between service quality and student satisfaction in private universities. The findings of this study is also consistent with the study by Mang'unyi \& Govender (2014), which also revealed that there is a positive relationship between service quality and student satisfaction in private universities, although a different scale, thus the HEdPERf scale was adopted for that study. Other studies such as Ravichandran, Kumar and Venkatesan (2012) and Kumar and Yang (2014) also adopted the HEdPERf scale in conducting a similar study and confirmed a positive relationship between service quality and student satisfaction. Other studies such as Brady et al. (2002), Clemes, Gan \& Kao (2008), also adopted a different scale in evaluating the relationship between service quality and student satisfaction. This shows the consistency in the relationship between service quality and student satisfaction, irrespective of the scale used.

\section{Conclusion and Managerial Implications}

In view of the level of competition in the service industry, firms, regardless of size and industry focus on quality of services offered as it plays a crucial role in gaining competitive advantage as well as attracting and retaining profitable customers. This is particularly apparent among higher educational institutions as they face an increasing competition from local and international education providers. The main objective of this study is to investigate the impact of service quality on student satisfaction in Private Ghanaian Universities and to examine the moderating role of brand positioning in the relationship between service quality and student satisfaction. The study revealed that age and gender does not account for a significant variation in the level of student satisfaction in private universities in Ghana. The results also revealed that there is a significant positive relationship between service quality and student satisfaction in Private Ghanaian Universities, thus, service quality dimensions such as responsiveness, reliability, and empathy had significant positive impact on student satisfaction, whilst tangibility and assurance contributes to determine student satisfaction to a very minimal degree. The results indicate however, that brand positioning was not statistically significant in determining the level of student satisfaction.

Based on these findings, it is recommended that private universities should adopt measures to attract more students who fall into the category of mature students in addition to the already existing regular category of students since their ages does not in any way affect their level of satisfaction as students in private institutions. This will enable private universities to improve on their student numbers and improve on their profitability as well. 
This is crucial since most private universities in Ghana are going through challenging circumstances as a result of their inability to attract students in recent times. The authors also recommend that private universities must take steps to enhance on the delivery of service quality since it plays a major role in the satisfaction of students. This has become necessary in view of the fact that studies have revealed that student satisfaction leads to student loyalty, since satisfied customers in general and students in this particular situation are always more credible to be loyal to a firm (Lee \& Lin, 2005) and also tend to be less price sensitive, buy more of the firm's products, are hardly influenced by competitors and are known to stay longer in a relationship with the provider (Zineldin, 2000). Previous studies have also revealed that within the context of higher education, satisfaction may influence a student's desire to remain with or leave a college, and their inclination to provide word-of-mouth recommendations (McGregor, 2017). Therefore, when students are satisfied with the level of service quality, they are inclined to stay loyal to the university by completing their programmes at those same institutions and returning even after their current programmes to pursue other programmes like masters and other short courses or professional programmes. They might also be inclined to provide positive word-of-mouth to friends and relatives, thus, in this case working as apostles for the institution. This will make it possible for private universities to attract more students even when it is difficult to attract students.

\section{Limitations and Suggestions for Future Research}

There are a number of limitations of this study. One limitation is related to the scope of the study which is limited to the education industry, specifically private tertiary education industry in Ghana. What this means is that the findings of this study may apply to the private tertiary education industry and may not be generalized directly to other industries such as public tertiary education industry, the airline or the financial services industry. Based on this, it is recommended that future research should include other industries such as the financial services industry and the airline industry so that the findings of these studies can be generalized across other industries. Again a mixed method approach or qualitative approach could be adopted for the same study in the future since this study adopted a quantitative approach to the study. Despite these limitations, the study offers practical recommendations on how private tertiary educational institutions can continue to improve on the level of student satisfaction. Therefore, it is expected that private universities which implement these recommendations will be able to achieve a competitive urge over other tertiary institutions, whether private or public in terms of student satisfaction and loyalty which will ultimately lead to enhancement in their profitability and continued survival in the face of stiff and turbulent challenges in the service industry in general and specifically in the tertiary education industry in Ghana.

\section{References}

Abd Manaf, N. H., Ahmad, K., \& Ahmed, S. (2013). Critical factors of service quality in a graduate school of Malaysia. International Journal of Quality and Service Sciences.

Acheampong, K. (2007). Educational Expansion and Access in Ghana: A Review of 50 Years of Challenge and Progress. Sussex: Centre for International Education University of Sussex, UK .

Adikaram, C., Yajid, M., \& Khatibi, A. (2015). Dimensions of Service Quality at Private Higher Education Institutions in Sri Lanka. European Journal of Business and Management, 7(30), 16-30.

Ahmad, M., \& Hassan, Y. B. (2015). Funding the Sub-Saharan African education sector with waqf: Experiences from al-Azhar university and selected universities in Malaysia. Journal of Creative Writing| ISSN 2410$6259,1(02), 40-54$.

Aiken, L. S., West, S. G., \& Reno, R. R. (1991). Multiple regression: Testing and interpreting interactions. sage.

Ali, F., Zhou, Y., Hussain, K., Nair, P. K., \& Ragavan, N. A. (2016). Does higher education service quality effect student satisfaction, image and loyalty?. Quality assurance in education.

Alves, H. \& Raposo, M. (2007). Conceptual model of student satisfaction in higher education. Total Quality Management, 18(5), 571-588.

Alves, H. \& Raposo M (2010). The influence of university image on students' behavior. International Journal of Educational Management, 24 (1), 73-85.

Ananth, A., Ramesh, R., \& Prabaharan, B. (2011). Service quality gap analysis in.

Anderson, J. C., \& Gerbing, D. W. (1988). Structural equation modelling in practice: A review and recommended two-step approach. Psychological bulletin, 103(3), 411.

Andreassen, T. W., \& Lindestad, B. (1998). Customer loyalty and complex services: The impact of corporate image on quality, customer satisfaction and loyalty for customers with varying degrees of service expertise. International Journal of Service Industry Management, 9(1), 7.

Angell, R., Heffernan, T., \& Megicks, P. (2008). Service quality in postgraduate education. Quality Assurance in Education, 16(3), 236-54.

Angulo-Ruiz, L. F., \& Pergelova, A. (2013). The student retention puzzle revisited: The role of institutional image. Journal of Nonprofit \& Public Sector Marketing, 25(4), 334-353. 
Annamdevula, S. (2016). The effects of service quality on student loyalty: the mediating role of student satisfaction. Journal of Modelling in Management, 11(2), 446-462.

Arbuckle, J. L. (2006). Amos (Version 7.0) [Computer Program]. Chicago: SPSS.

Asubonteng, P., McCleary, K. J., \& Swan, J. E. (1996). SERVQUAL revisited: a critical review of service quality. Journal of Services marketing.

Belanger, C., Mount, J., \& Wilson, M. (2002). Institutional image and retention. Tertiary Education \& Management, 8(3), 217-230.

Bellini, C. G. P., Lunardi, G. L., \& Henrique, J. L. (2005). Service quality in banks: Insights from the Brazilian Experience.

Berger, K.A. \& Wallingford, H.P (1996). Developing Advertising and Promotion Strategies for Higher Education. Journal of Marketing for Higher Education, 7 (4), 61-72.

Brady, M. K., Cronin Jr, J. J., \& Brand, R. R. (2002). Performance-only measurement of service quality: a replication and extension. Journal of business research, 55(1), 17-31.

Brown, R. M., \& Mazzarol, T. W. (2009). The importance of institutional image to student satisfaction and loyalty within higher education. Higher education, 58(1), 81-95.

Burns, R. (2000). Introduction to research methods, 4th edition. Frenchs Forest: Longman.

Butcher, K., Sparks, B., \& O’Callaghan, F. (2001). Evaluative and relational influences on service loyalty. International Journal of Service Industry Management.

Buttle, F. (1996). SERVQUAL: Review, critique and research agenda. European Journal of Marketing, 30(1), 832.

Carrillat, F. A., Jaramillo, F., \& Mulki, J. P. (2007). The validity of the SERVQUAL and SERVPERF scales: A meta-analytic view of 17 years of research across five continents. International Journal of Service Industry Management, 18(5), 472-490.

Cassidy, E. D., Colmenares, A., Jones, G., Manolovitz, T., Shen, L., \& Vieira, S. (2014). Higher education and emerging technologies: Shifting trends in student usage. The Journal of Academic Librarianship, 40(2), 124133.

Chih, W-H., Wang, K-Y., Hsu, L-C., \& Cheng, I-S. (2012). From disconfirmation to switching: an empirical investigation of switching intentions after service failure and recovery. The Service Industries Journal, 32 (8), 305-1321.

Chung, E., \& McLarney, C. (2000). The classroom as a service encounter: Suggestions for value creation. Journal of Management Education, 24(4), 484-500.

Clemes, M. D., Gan, C., Kao, T. H., \& Choong, M. (2008). An empirical analysis of customer satisfaction in international air travel. Innovative Marketing, 4(2), 50-62.

Cronin, J.J. \&Taylor, S.A. (1992). Measuring service quality: a re-examination and extension. Journal of Marketing, 56, July, 55-68.

Cronin Jr, J. J., \& Taylor, S. A. (1994). SERVPERF versus SERVQUAL: reconciling performance-based and perceptions-minus-expectations measurement of service quality. Journal of marketing, 58(1), 125-131.

Cuthbert, P.F. (1996). Managing service quality in HE: is SERVQUAL the answer? Part 1. Managing Service Quality, 6 (2), 11-16.

Davis, Ronald GD. "Global positioning system receiver enclosure." U.S. Patent Application 29/089,536, filed June $6,2000$.

Díaz-Méndez, M., \& Gummesson, E. (2012). Value co-creation and university teaching quality: Consequences for the European Higher Education Area (EHEA). Journal of Service Management, 23(4), 571-592.

Donaldson, B., \& McNicholas, C. (2004). Understanding the postgraduate education market for UK-based students: a review and empirical study. International Journal of Nonprofit and Voluntary Sector Marketing, 9(4), 34660.

Đonlagić, S., \& Fazlić, S. (2015). Quality assessment in higher education using the SERVQUAL model. Management, 20(1), 39-57.

Edema, A. J. M (2012). Public Relations: Tools and Techniques in Marketing Communications. Public Relations Journal, 8 (1), 11-15.

Ehigie, B. O. (2006). Correlates of customer loyalty to their bank: a case study in Nigeria. The International Journal of Bank Marketing, 24(7), 494-508.

Elliott, K. M., \& Healy, M. A. (2001). Key factors influencing student satisfaction related to recruitment and retention. Journal of marketing for higher education, 10(4), 1-11.

Ellwood, I. (2009), Brand strategy, in: Brands and Branding, ed. R. Clifton, Profi le Books Ltd.

Ericksson, K., \& Lofmarck, V. A. (2000). Customer retention, purchasing behaviour and relationship substance in professional services. Industrial Marketing Management, 29(4), 363-372.

Firdaus, A. (2006a). The development of HEdPERf: a new measuring instrument of service quality for the higher education sector. International Journal of Consumer Studies, 30 (6), 569-81. 
Fornell, C., \& Larcker, D. F. (1981). Structural equation models with unobservable variables and measurement error: Algebra and statistics.

Giannakisa, M., \& Bullivantb, N. (2015). The massification of higher education in the UK: Aspects of service quality. Journal of further and higher Education, 1-19.

Gotlieb, Jerry B., Dhruv Grewal, \& Stephen W. Brown (1994). Consumer Satisfaction and Perceived Quality: Complementary or Divergent Constructs? Journal of Applied Psychology, 79 (6), 875-85.

Gruber, T., Szmigin, I., Voss, R. (2010). Handling customer complaints effectively. Managing Service Quality,19 (6), 636-656.

Hair, J., Black, W., Babin, B., \& Anderson, R. (2010). Multivariate data analysis: A global perspective (7th ed.). London: Pearson International.

Hamad, S., \& Naintara, S. R. (2014). The Impact of Service Quality on Customer Satisfaction, Customer Loyalty and Brand Image: Evidence from Hotel Industry of Pakistan. Middle-East Journal of Scientific Research 19 (5): 706-711, 2014, 19(5), 706-711.

Ham, L., \& Hayduk, S. (2003). Gaining competitive advantages in higher education: analyzing the gap between expectations and perceptions of service quality. International Journal of Value-Based Management, 16(3), 223-242.

Hasan, H. F. A., Ilias, A., Rahman, R. A., \& Razak, M. Z. A. (2008). Service quality and student satisfaction: A case study at private higher education institutions. International Business Research, 1(3), 163-175.

Janiszewska, K., \& Insch, A. (2012). The strategic importance of brand positioning in the place brand concept: elements, structure and application capabilities. Journal of International Studies, 5(1).

Johnson, F.C. \& Golomskiis, W.A.J. (1999). Quality concepts in education. The TQM Magazine, 11 (6), $467-73$.

Joseph, M. \& Joseph, B. (1997). Service quality in education: a student perspective. Quality Assurance in Education, 5 (1), 15-21.

Judson, K. M., Aurand, T. W., Gorchels, L., \& Gordon, G. L. (2008). Building a university brand from within: University administrators' perspectives of internal branding. Services Marketing Quarterly, 30(1), 54-68.

Keller, K.L. (1998). Strategic Brand Management in: Building, Measuring, and Managing Brand Equity, Prentice Hall, New Jersey.

Khoo, S., Ha, H., \& McGregor, S. L. (2017). Service quality and student/customer satisfaction in the private tertiary education sector in Singapore. International Journal of Educational Management.

Kim, S. \& Jin, B. (2002). Validating the retail service quality scale for US and Korean customers of discount stores: an exploratory study. Journal of Services Marketing, 16 (3), 223-37.

Koni, A., Zainal, K., \& Ibrahim, M. (2013). An Assessment of the Services Quality of Palestine Higher Education. International Education Studies, 6(2), 33-48.

Koslowski, F.A. III (2006). Quality and assessment in context: a brief review. Quality Assurance in Education, 14 (3), 277-88

Kotler, P., \& Keller, K. (2006). Marketing Management, 12th edition. New Jersey: Pearson, Prentice Hall.

Kumar, S. A., Mani, B., Mahalingam, S., \& Vanjikovan, M. (2010). Influence of Service Quality on Attitudinal Loyalty in Private Retail Banking: An Empirical Study. IUP journal of management research, 9(4).

Ledden, L., Kalafatis, S. P., \& Mathioudakis, A. (2011). The idiosyncratic behaviour of service quality, value, satisfaction, and intention to recommend in higher education: An empirical examination. Journal of Marketing Management, 27(11/12), 1232-1260.

Lee, J. L., Kim, Y., \& Won, J. (2018). Sports brand positioning. International Journal of Sports Marketing and Sponsorship.

Lee, J. W., Miloch, K. S., Kraft, P., \& Tatum, L. (2008). Building the brand: A case study of Troy University. Sport Marketing Quarterly, 17(3), 178-182.

Lehtinen, U., \& Lehtinen, J. R. (1991). Two approaches to service quality dimensions. Service Industries Journal, 11(3), 287-303.

Mai, L. W. (2005). A comparative study between UK and US: The student satisfaction in higher education and its influential factors. Journal of marketing management, 21(7-8), 859-878.

Mahapatra, S.S. \& Khan, M.S. (2007). A neural network approach for assessing quality in technical education: an empirical study. International Journal of Productivity and Quality Management, 2 (3), 287-306.

Markus, H., \& Hendry, R. (2015). Exploring the mediating role of affective and cognitive satisfaction on the effect of service quality on loyalty. Total Quality Management \& Business Excellence, 26 (9/10), 971-985.

McGregor, S. K. (2017). Service quality and student/customer satisfaction in the private tertiary education sector in Singapore. International Journal of Educational Management, Vol., 31(4), 1-17.

Meuter, M. L., Ostrom, A. L., Roundtree, R. I. \& Bitner, M. J. (2000) Self-service technologies: understanding customer satisfaction with technology-based service encounters, Journal of Marketing 64(3), 50-64.

National Accreditation Board. (2020). Retrieved from National Accreditation Board Web Site: https://nab.gov.gh. Ndubisi, N. O. (2007). Relationship quality antecedents: the Malaysian retail banking perspective. International 
Journal of Quality \& Reliability Management.

Neuman, L. W. (2007). Social research methods, 6/E. Pearson Education India.

Odoom, R., \& Mensah, P. (2018). Brand orientation and brand performance in SMEs: The moderating effects of social media and innovation capabilities.

Oduro, A., \& Senadza, B. (2004). Cross-border provision and the future of Higher Education in Africa - A Case Study of Ghana. Paper Prepared for the 11th General Conference of the Association of African Universities (AAU) to be Held in Cape Town, South Africa, from 21 - 25 February 2005.

Oliver, R. (1999). Whence customer loyalty? Journal of Marketing(63), 33-44.

Oliver, R.L. (1980). A cognitive model of the antecedents and consequences of satisfaction decisions. Journal of Marketing Research, 17 (4), 460-9.

Oliveria, T.,\& Pereia, P. (2009). Who pays the bill? Study cost and student's income in Portuguese higher education. European Journal of Education, 24(1), 111-121.

Olorunniwo, F., Hsu, M. K., \& Udo, G. J. (2006). Service quality, customer satisfaction, and behavioural intentions in the service factory. Journal of services marketing.

Palacio, A. B., Meneses, G. D., \& Pérez, P. J. P. (2002). The configuration of the university image and its relationship with the satisfaction of students. Journal of Educational administration.

Parasuraman, A., Zeithaml, V.A. \& Berry, L.L. (1985). A conceptual model of service quality and its implications for future research. Journal of Marketing, 49 (4), 41-50.

Parasuraman, A., Zeithaml, V.A. \& Berry, L.L. (1988). SERVQUAL: a multiple-item scale for measuring consumer perceptions of services quality. Journal of Retailing, 64 (1),12-40.

Parasuraman, A., Zeithaml, V.A. \& Berry, L.L. (1991). Refinement and reassessment of the SERVQUAL scale. Journal of Retailing, 67 (4), 420-50.

Ping Jr, R. A. (1995). A parsimonious estimating technique for interaction and quadratic latent variables. Journal of marketing research, 32(3), 336-347.

Purgailis, M., \& Zaksa, K. (2012). The impact of perceived service quality on student loyalty in higher education institutions. Journal of Business Management, 6(6), 138-152.

Rinehart, G. (1993). Quality Education: Applying the Philosophy of Dr. W. Edwards Deming to Transform the Educational System, ASQC Quality Press, Milwaukee, WI.

Rood, A. S. \& Dziadkowiec, J. (2013). Cross Cultural Service Gap Analysis: Comparing SERVQUAL Customers and IPA Mystery Shoppers. Journal of Foodservice Business Research, 16 (4), 359-377.

Schlesinger, W., Cervera, A., \& Pérez-Cabañero, C. (2017). Sticking with your university: The importance of satisfaction, trust, image, and shared values. Studies in Higher Education, 42(12), 2178-2194.

Sevier, R. A. (1994). Image Is Everything--Strategies for Measuring, Changing, and Maintaining Your Institution's Image. College and University, 69(2), 60-75.

Senthilkumar, N., \& Arulraj, A. (2011). SQM-HEI - determination of service quality measurement of higher education in India. Journal of Modelling in Management, 6(1), 60 - 78.

Seth, N., Deshmukh, S.G. \& Vrat, P. (2005). Service quality models: a review. International Journal of Quality \& Reliability Management, 22 (9), 913-49.

Tarí, J. J. \& Dick, G. (2016). Trends in quality management research in higher education institutions. Journal of Service Theory and Practice, 26 (3).

Teeroovengadum, V., \& Kamalanabhan, T. (2016). Measuring service quality in higher education: Development of a hierarchical model (HESQUAL)",. Quality Assurance in Education, 24(2), 244-258.

Temporal, P. (2002), Advanced Brand Management. From Vision to Valuation, John Wiley \& Sons, Singapore.

$\mathrm{Wu}$, H.-C. (2013). An empirical study of the effects of service quality, perceived value, corporate image, and customer satisfaction on behavioural intentions in the Taiwan quick service restaurant industry. Journal of Quality Assurance in Hospitality \& Tourism, 14(4), 364-390.

Yeo, R. K. (2008). Brewing service quality in higher education. Quality Assurance in Education, 16(3), 266 - 286.

Yusoff, M., McLeay, F., \& Woodruffe-Burton, H. (2015). Dimensions driving business student satisfaction in higher education. Quality Assurance in Education.

Zainal, N. S., Shaharudin, M. R., \& Jusoff, K. (2010). Service quality perceptions between cooperative and Islamic Banks of Britain. American Journal of Economics and Business Administration, 2(1), 1-5.

Zaibaf, M., Taherikia, F., \& Fakharian, M. (2013). Effect of perceived service quality on customer satisfaction in hospitality industry: Gronroos' service quality model development. Journal of Hospitality Marketing \& Management, 22(5), 490-504.

Zeithaml, V.A. \& Bitner, M.J. (2003). Services Marketing: Integrating Customer Focus Across the Firm, Irwin McGraw-Hill, Boston, MA.

Zeithaml, V. A., Berry, L. L., \& Parasuraman, A. (1996). The behavioural consequences of service quality. Journal of marketing, 60(2), 31-46.

Zeithaml, Valarie A., Leonard L. Berry, \& A. Parasuraman (1996). The Behavioural Consequences of Service 
Quality. Journal of Marketing, 60 (April), 31-46.

Zineldin, M. (2000). TRM, Total Relationship Management. Lund: Studentlitteratur.

Zineldin, M. (2006). The quality of health care and patient satisfaction. International journal of health care quality assurance. 